ISSN 2449-7479

eISSN 2543-8840

amme.wne.sggw.pl

Annals of Marketing Management \& Economics

Vol. 4, No 1, 2018, 5-24

DOI 10.22630/AMME.2018.4.1.1

\title{
INFLUENCE OF COMMUNICATION OF MEDICAL PERSONNEL WITH PATIENTS ON HEALTH CARE UNITS MANAGEMENT PROCESSES
}

\author{
Bożena Freund \\ Jagiellonian University, Poland
}

\section{INTRODUCTION}

There are no doubts that management in public health care units is one of the greatest challenges for contemporary public services systems. The most important issues which appear in the management process of health care units, particularly the public ones, are: mission, vision, values and ethics. Mission of a health care organisation defines a purpose of existence and reasons for which an institution works from the patient's point of view, taking into consideration personnel's interests as well [Durlik 2008]. A social mission, in health care units, is an idea related to each aspect of an organisation's activity, aiming at improvement of health condition and quality of a society's life. Vision, in turn, defines a long-term unit's future by stating what is it now and what it desires to be in a definite perspective. Vision presents as well a set of basic moral and ethical values within which health care organisation intends to operate. Vision should be expressed in a way that enables emotional engagement of medical personnel and supporting staff, as well as patients and environment in which an institution operates [Durlik 2008]. As it was said, 'values and ethics are deeply embedded in a health care, and most of people who work in health care units present an altruistic belief regarding a social value of the pursued work' [Walshe and Smith 2011]. Vision, mission and values should be properly expressed in an organisation operation by a proper communication of medical personnel with patients, especially because "today's generation expects more of a health care that their parents. A society does not want to be a passive consumer of health care services which are served by service providers at their discretion. Patients, who are used to wide range of choice, as well as freedom of decision taking in other aspects of life (...) expect that they will be consulted, informed and included in taking decisions which concern their health" [Walshe and Smith 2011]. 
The basis is therefore communication of medical personnel with patients, which involves conversation techniques, motives for actions, attitudes and behaviours towards a patient which result from a professional role, and an expression role which allows understanding as well as satisfying patients' expectations and needs. Sufficiently advanced communication skills of medical personnel are vital from the perspective of a patient who has found himself/herself in a difficult situation of a sickness and hospitalisation. Situation of a medical care, particularly a hospital care involves a severe stress, what was pointed out by Holmes and Rahe, who developed the Hospital Stress Scale which involves 49 items, ranged in accordance with the increase of their impact [according to: Wojtczak 1994]. On the basis of the above mentioned scale it can be concluded how important is information to patients, and what is its impact on a level of satisfaction with communication with medical staff, which is still low. A lack of that important factor leads to disorientation as well as stresses a patient, what directly influences their condition, and so it makes longer the process of recovery and stay in a hospital, what is equally inconvenient to the patient, medical personnel, taxpayers, and a unit manager, as longer hospitalisation of a patient means a huge logistical challenge to a unit. If a proper communication with a patient was provided, not only the patient would feel much better, what would directly affect the process of recuperation, but also it would contribute to improve effectiveness of medical personnel's as well as a unit's work, and create a possibility of inpatient treatment for those who need it, thanks to which waiting time to hospitals and specialists could be reduced. When it comes to time which is given to communication, interviews made in Warsaw Oncology Centre show that 'in the time of a twenty-minutes appointment (oncologists appointment time is above the average) only one minute is set aside to patient's questions. After all, patients do not know most of the terminology which is used by doctors. As a result every second patient claims that he/she hasn't learned anything about the cause of a disease, and the same number of patients, after another equally hermetic appointment, stops to obey doctors' recommendations' [Szulc 2011]. The author addressed a very important issue which is a direct impact of communication on a therapy effectiveness, as the substantial function of an information exchange between a patient and medical personnel is to make a diagnosis, and then define further treatment in order to cure a patient. That is just one out of a few functions of communication in this complex relation, as another one, and in some cases (for instance chronic disease) an essential function is a function which involves support, emotional comfort of a fear and improving patient's psychophysical condition. A patient who finds himself/herself in such a difficult situation may be frustrated by adverse external factors which cause unpleasant feeling, i.e. anxiety, fear, dread, pain and loneliness. Dependence, strictly related to the fact that care is provided by strange persons, is as well a difficult situation to a patient. A patient feels lack of control and influence on a situation. He/she can feel lost in a maze of medical procedures, which are not understandable to him/her, or specialist language. Such a psychophysical condition results in a negative emotional attitude, specified behaviours or means of communication. A patient's attitude may vary from a defend one, by irritation, to aggression [Baum and Staszewski 2008]. The significance of communication in fear decreasing in patients is stressed by Rudawska who states that 'patient, by choosing a specialist, entrusts in him/her his/her health, therefore he/she expects signals which confirm the choice made was right. In situations which exclude discretion of making 
decisions, patient's anxiety increase causing emotional tension which is often not realised. The role of communication is then even more important as apart from a persuasive function, it is a creator of trust to a services provider' [Rudawska 2006]. As a result there can be distinguished four basic dimensions of relation which decide on development of a bond between a patient and a services provider: a technical dimension, a social dimension, a moral dimension, and a cognitive dimension. A technical dimension refers to a basic and traditionally understood treatment which involves medical activities related to diagnosis and therapy. This is the core of medical professions, and in interventional specialisations (e.g. surgery) it is of an invasive character. A social dimension refers to communication sphere between parties, it is of verbal and non-verbal character. The way conversation in conducted, the way of asking questions, clearness of expression, as well as all this what is included in the code of a body language, eye contact, touch - affect quality as well as effectiveness of communication with a patient. In many conditions communication affects a mental sphere, e.g. the emotional sphere of patient's treatment. An effective communication is related to a technical dimension, as in many cases it is the basis of diagnosis and treatment, and in chronic diseases - an essential element of a therapy. A moral dimension relies on a patient's trust in medical personnel. Between trust and communication there is a feedback, as creating a relation which is based on trust supports an efficient communication. Gaining somebody's trust is a condition for moving a relation to a cognitive dimension, which refers to the level of engagement in a treatment of both a patient and a medical personnel. The engagement directly affects the quality of relations by shaping attitudes and behaviours of a relation participants, it has as well real impact on the course of treatment [Rudawska 2006]. Authors of an important handbook regarding an effective communication between doctors and patients stress out that ability of medical personnel to communicate with a patient is one of the most important factors in a treatment process [Wojtczak 1994]. It is the ground for diagnosis and treatment, and in the case of chronic diseases it is a fundamental form of therapy. The role of communication ability in the process of treatment can be put in four aspects: informing, diagnosing, psychotherapy, and integration. Communication of medical personnel with a patient is performed in various ways and in various forms. Nevertheless, it can be divided into verbal communication, i.e. verbal transmission of information, and non-verbal communication which involves so called 'codes of body language' (mimicry, gesticulation, tone and voice sound). Both of these methods are equally important and they complement each other. A competent application of both these methods makes an interaction effective [Wojtczak 1994], and a treatment - successful. 'A basis for such finding are results of empirical studies which confirm the hypothesis that a major part of a treatment effect is the result of a constructive communication between a doctor and a patient' [Rudawska 2006]. Depending on a personality, an attitude, and few other factors there can be noticed various forms of relations with a patient which are applied by a medical personnel. Bartkowiak distinguishes four basic forms of relations which can occur between a patient and a medical personnel. First of them is 'the paternalist model in which it is a doctor who decides what type of treatment is most suitable and tries to make a patient to agree; another one is the information model in which a doctor as a professional expert provides information and a patient makes a decision regarding treatment methods; another one is an interpretation model in which a doctor provides information both on a patient's condition and risks 
as well as advantages related to various types of treatment (a doctor acts in this model as well as an advisor who helps a patient in making a decision regarding procedures which are most suitable to patient's personality); the other one is the model of joint consultation in which a doctor, as a teacher and a friend, starts a dialogue with a patient in order to consider all advantages and disadvantages of various methods and choose the most appropriate treatment' [Bartkowiak 2010]. The latter model is as well-supported by other authors. In practical terms it is a model of relations which is most desired and advantageous.

It is therefore shown that a contemporary patient requires from a medical personnel, apart from high professional qualifications, specialist knowledge, lifelong learning and relevant professional experience, a widely understood communication which involves both a transfer of information regarding a health condition and a lot of empathy and partner support instead of paternalist moralizing and giving orders. Medical procedures, communication, trust, and engagement may prove to be key elements in a treatment process which directly affect a therapy effectiveness, a patient's and personnel's satisfaction, and even effectiveness of a health care institution. This is also an important question, as even without it Polish health care system faces many problems. Most of them however are out of a manager's control. Nevertheless, there are many issues in particular health care units which can be improved and - by doing this - improve the quality of health care. One of the most important questions on which a manager, head or director of a health care unit has a major impact is the issue of communication between medical personnel and patients. It is essential for a manager to remember about it, as it turns out that medical students of all professions are particularly required to constant enhancement of their knowledge regarding widely understood medical sciences with some elements of ethics, which is a separate academic subject but should be also emphasised in other courses. Lectures in communication or psychology are considered as an additional element to a basic medical knowledge, and they are still marginalised. Studies performed in 2016 in which, among others, the Regulation of the Minister of Science and Higher Education of $9^{\text {th }}$ May 2012 on educational standards for the fields of study: Medical Major, Dentistry, Pharmacy, Nursing and Obstetrics was analysed, proved that social sciences related courses (including medical personnel soft competences development) are required to complete as a part of a study programme only to the minimum extent. For example, 6-years Medical Major programme covers totally 5,700 hours of courses and practical placements, and only 240 hours of the total number are dedicated to lectures in social sciences, which is just $4.21 \%$ of all courses. In turn, the total number of hours at a firs-cycle and second-cycle programmes in Nursing covers 6,020 hours of lectures, tutorials, and practical placements out of which only 450 hours are dedicated to workshops regarding social sciences which is $7.47 \%$ of the total time dedicated to education of nurses [Freund and Dorczak 2016].

It was not until middle 1990s, when a public debate regarding the significance as well as impact of communication on the quality of relations with a patient and a treatment process. There are still only few studies regarding a proper communication with a patient, similarly seminars and conferences. It should be stressed however that with the beginning of the new millennium interest in communication rises and consequently the issue becomes more and more significant. This time it is not only about improving relations with patients, but also about improving effectiveness of a health care unit 
activity, where an effective communication not only creates a positive spirit in a health care unit, but also becomes a part of creating a positive image of a unit and an important factor of a competitive advantage. Therefore, current motives for improving quality of communication with patients are market-oriented, nevertheless they can bring real advantages not only to a health care unit and medical personnel, but also patients and the whole society. It happens more and more often that health care units managers send their staff to special trainings, seminars and conferences, aiming at effectiveness improvement, particularly knowing that there are three basic types of skills which are nowadays required from a medical personnel: intellectual skills, practical skill, and communication skills. Within the scope of intellectual skills, there are specialist knowledge as well as the ability to properly apply the knowledge. Within the scope of practical skills there are proficiency in performing medical procedures as well as constant experience acquiring. Within the range of communication skills there are in the first place empathy, sensitivity, an individual approach towards a patient, ability to react to other's needs, as well as acquiring knowledge regarding psychology, which significantly improves the communication process [Wojtczak 1994]. As it can be seen, all the three scopes of skills are indispensable for medical personnel in order to achieve professionalism. Communication is in this process as much important as knowledge and competences. The significance of communication was as well noticed in legal regulations and it was entered in ethical codes for particular professional medical groups. In the Ethical Code for Medical Doctors chapter 1 is dedicated to respect for a patient's rights. Similar recommendations in regard to communication with patients can be found in the Code of Professional Ethics for Nurse and Midwife in the Republic of Poland. Both nurses and midwives in their vow in point 4 swear to "show respect to patients, not to misuse their trust, as well as observe professional secrecy". In the specific part, which covers relations between a nurse and a patient, in point 1 it is stated that "a nurse in her professional role is obliged to (...) provide a patient with a reliable and understood information regarding a nursing process", further in point 2 it is stated that "in cooperation with a patient a nurse should act with kindness, forbearance, patience, creating the atmosphere of mutual trust and understanding" [Code of Professional Ethics for Nurse and Midwife in the Republic of Poland]. Quite similar regulations can be found in the first coherent Code of Professional Ethics for Paramedics, and in other ethical codes of medical professionals. "Numerous experiments show the significance of empathy within the scope of improving interpersonal contacts, particularly in a relation doctor-patient. (...) A therapist's ability to recognise his/her own as well as others' emotional conditions decides on a proper perception of a patient's affective sphere. (...) Therefore, the more empathy, the better perception and understanding of their own and others' emotional conditions. (...) An empathic doctor is therefore not only an efficient specialist, but also a spiritual comforter, guardian and advisor" [Wojtczak 1994]. We must be aware that empathy is necessary so that communication with patients works properly. It turns out that communication based on empathy may be an effective addition to a therapy, as thanks to empathy medical personnel may ease emotional consequences of a disease (reduction of fear, anger, feel of wrong, depression, perplexity, helplessness), and mentally strengthen a patient in his/her struggle with a disease or adjustment to a disease (raising faith and hope, self-esteem, sense of support, sense of control, sense a situation understanding, 
sense of meaning, sense of internal strength and motivation for treatment) [Motyka 2012]. Communication based on ethics and empathy may have a real impact on a patient's condition. One should however remember that truly professional support may be effective only if it meets basic requirements, such as: competences, engagement, cooperation, and communication [Krzyżanowska-Łagowska 2005]. These are basic features which are necessary in order to acquire high work effectiveness of medical personnel, as well as an expected effectiveness of activities performed by health care units. It should be as well mentioned that, basing on ethical codes of particular medical professions, it is medical personnel who are responsible for the quality of communication with patients, that's why it is so important to develop proper attitudes. What's more, the relation level of complexity puts as well a great deal of responsibility for this communication in medical personnel, as complexity of this relation 'on the one hand results from disadvantageous situation in which one of the communication party found himself/herself (a patient), and on the other hand - from the specificity of the communication subject (a disease)' [Krzyżanowska-Łagowska 2005]. The above indicates as well that relation between a patient and medical personnel is of strongly asymmetric character, which means that it generally depends on a therapist whether his/her cooperation with a patient will be consonant, advantageous to both parties, or full of tensions, stresses and misunderstanding. In order to avoid the latter possibility, medical personnel should try to fulfil patient's expectations both in information and emotional sphere. Meanwhile, according to patients' opinions, medical personnel's contact with a patient regards mainly a diagnosis [Wojtczak 1994]. What are then most common irregularities? The most common mistakes in communication with patients which are made by medical personnel, are among others: blaming a patient for the course of disease (manifested by moralising, numerous accusations, raising voice, what increases patient's sense of guilt, which is without it high enough), seeing patient's problems from their own perspective and imposing their opinion (it is viewing a patient through values characteristic of medical personnel, stereotype viewing), false sympathy (which may lead to improper calming a patient, e.g. telling untruth, withholding information, promising impossible things), inaccuracy in ordering and signing recommendations [Wojtczak 1994], or misusing specialist terminology or even jargon which is not understood to people outside medical sector. Other often mentioned defaults in communication are among others: treating patients tactlessly, impersonally; lack of interest in patient's emotions and lack of attention given to patient's emotions. We should consider why do so many mistakes in communication occur. The easiest answer is to blame insensitive medical personnel, however it would be very unfair and mostly false statement. The main reason is to be found in the lack of education in communication skills during first-cycle programmes and second-cycle programmes, as well as neglecting psychological issues. Lack of proper communication may as well be a result of individual cases of low empathy of medical personnel, however - what is important - empathy is a feature which can be, and even ought to be developed and cherished throughout the whole life, that's why there is a great chance for improvement of communication processes with patients. Blaming only an educational system or individual features of some representatives of medical staff as the only reasons of improper communication with patients would be unfair, for this reason an increased level of stress under which medical staff works everyday should 
be mentioned. Awareness of responsibility which lies with them is great, as everyday they deal with people's health, and even life. If such a burden is not properly alleviated (for instance because of lack of a proper system of human resources management in a facility), it can lead to a burnout, which is particularly dangerous phenomenon in a work of a public service character.

While discussing the significance of communication in health care units management, there ought to be mentioned marketing advantages related to an effective communication with patients. More and more authors emphasise a great importance of positive relations between medical personnel and patient in the promotion of a given unit. Wojtczak states that the ability to establish contact is an opinion-forming factor, what is supported by favourable opinions of patients on medical personnel of a given unit that they are not only outstanding specialists in their fields, but also approachable, kind and understanding people [Wojtczak 1994]. In turn, Rudawska points out a great importance of so called relations marketing based on trust, engagement, ethics of a medicine doctor, and efficient communication [Rudawska 2006]. It turns out that proper communication between a patient and medical personnel may bring not only individual advantages to a patient, or indicate high effectiveness of medical personnel's work, but also it may be the best, the most effective, and the cheapest form of marketing for a health care facility, letting managers use financial resources for much more urgent needs of an organisation, than expensive promotion. Thanks to this a director of a public health care unit may focus on priorities. A proper communication between a patient and medical personnel is essential for the perspective of a health care unit management also because of economic advantages. It is more precisely described by Rudawska who noticed that 'a basic condition of an exchange in a relation patient-service provider is trust which causes an engagement increase in a positive result of services providing' activity. The significance of trust goes further than a psychological and social spheres, becoming an economic category, which means that in longer periods of time it brings specific economic effects. Trust, which is a phenomenon that supports creating advantageous effects in a relation services provider-patient enables a services provider to stabilise relations with patients and increase in its competitiveness against other services providers, as relation based on trust and engagement becomes more valuable and precious than relations offered by market competition. From the perspective of a customer a real effect of trust in a relation is reduction of noticeable risk which is related to the fact of being a patient. A consequence of trust and engagement, which is substantial from both perspectives, is cooperation of parties to a relation in acquiring positive results in services related activity, what from a long-term perspective brings advantageous economic effects in the form of lower costs (reduction of number of visits and ordered drugs, reduction of hospitalisation length, reduction of the number of ordered examinations and tests)' [Rudawska 2006]. Therefore, communication which is a perfect way to develop and sustain patients' trust to medical personnel, as well as help to engage a patient in a treatment, becomes a strategic instrument in the context of health care unit management. Similarly, when communication is neglected it is very difficult to obtain trust, what results in difficulties in engagement creation, and in such situation patients will in large numbers turn to other health care units, what decreases effectiveness of a unit's activity. The above shows why it is so important to create in medical care sector employees a natural 
desire to actively communicate with patients, and then constantly improve this ability. Everyone makes mistakes in communication, and they are in fact inevitable, they cannot however dominate a relation between medical staff and patients.

To sum up, the literature indicates that communication, apart from a professional medical knowledge and practical experience, constitutes an inherent element of an effective treatment and may significantly influence the management of health care institutions. As it was shown, communication is significant from various point of view, thus the decision was made to make a study inquiring how important are these competences in the process of education, as well as in work in health care facilities. In relation to the above there were stated three hypothesis:

I: In the process of education there is only little time given to acquisition of communication skills regarding communication between a patient and medical personnel.

II: Medical personnel is satisfied with communication with patients.

III: Communication between medical personnel and patients may have an impact on the management of health care organisations.

\section{METHODS}

A study material was gathered in the first quarter of 2014. Medical personnel was addressed with a questionnaire which enclosed twelve closed questions with provided answer choices. In each question only one answer should have been marked. At the end of the questionnaire there was a respondent's particulars in which medical personnel were asked to indicate their profession, number of years worked in the profession, sex, as well as entering the date and place. In the final analysis questionnaires from 113 representatives of various medical professions were taken into consideration. Significant number of questionnaires were gathered via website, as it enabled reaching as many specialist as possible. The method of analysis is quantitative.

In the three following tables there is presented characteristics of the study group, dividing it into profession pursued, seniority and sex. In the process of respondents selection the intension was to provide diversity to the highest possible level.

TABLE 1. Characteristics of the study group in division into medical professions

\begin{tabular}{|l|c|}
\hline Medical profession & Number of questionnaires \\
\hline Nurses and midwives & 49 \\
\hline Paramedics & 21 \\
\hline Physiotherapists & 18 \\
\hline Medical doctors/dentists/surgeons & 17 \\
\hline Others & 5 \\
\hline No data & 3 \\
\hline Total sum & 113 \\
\hline
\end{tabular}

Source: author's own study on the basis of gathered study material. 
TABLE 2. Characteristics of the study group in division into seniority

\begin{tabular}{|l|c|}
\hline Seniority & Number of questionnaires \\
\hline From few months to 10 years & 76 \\
\hline $11-23$ years & 20 \\
\hline 24 years and more & 17 \\
\hline Total sum & 113 \\
\hline
\end{tabular}

Source: author's own study on the basis of gathered study material.

TABLE 3. Characteristics of the study group in division into sex

\begin{tabular}{|l|c|}
\hline Sex of respondents & Number of questionnaires \\
\hline Woman & 81 \\
\hline Man & 31 \\
\hline No data & 1 \\
\hline Total sum & 113 \\
\hline
\end{tabular}

Source: author's own study on the basis of gathered study material.

\section{STUDY RESULTS}

The first of hypothesis which were presented in the study concerned a little time which is dedicated in the process of medical staff education to develop communication skills between health care employees and patients. In order to verify the hypothesis medical personnel were asked three questions.

Answers given to the first question indicate that $49 \%$ of medical personnel believe that education concerning an effective communication with patients is in Poland insufficient and there should be more attention paid to the issue in the process of education. A detailed distribution of answers is presented in Figure 1.

To the question whether during education medical personnel attended courses in communication with a patient $65 \%$ of respondent answered yes. A detailed distribution of answers is presented in Figure 2.

Answers to another question proved that medical personnel generally do not attend trainings, conferences or read literature concerning a proper communication with patients (49\%). A detailed distribution of answers is presented in Figure 3.

When summing up the first assumption that in the process of education there is only little time dedicated to acquisition of communication skills concerning communication between a patient and medical personnel, the study results confirm its correctness. Answers given by respondents show that however $65 \%$ of them during professional 
1. Education concerning effective communication with patients in Poland is:

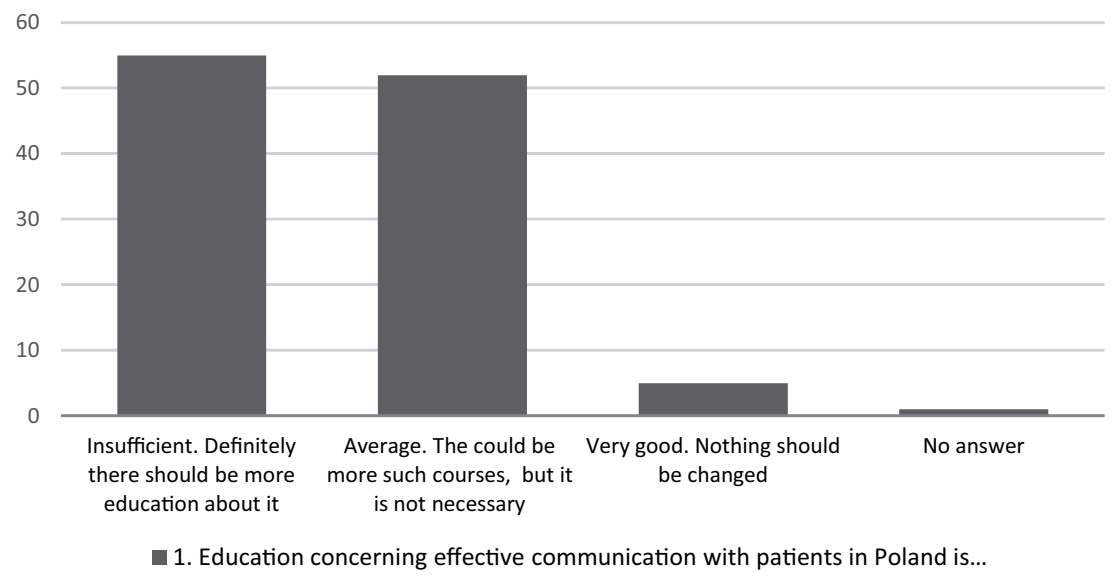

FIG. 1. Distribution of medical personnel answers to question no. 1

Source: author's own study on the basis of gathered study material.

2. Did you attend courses in a proper and effective communication with patients during your professional education?

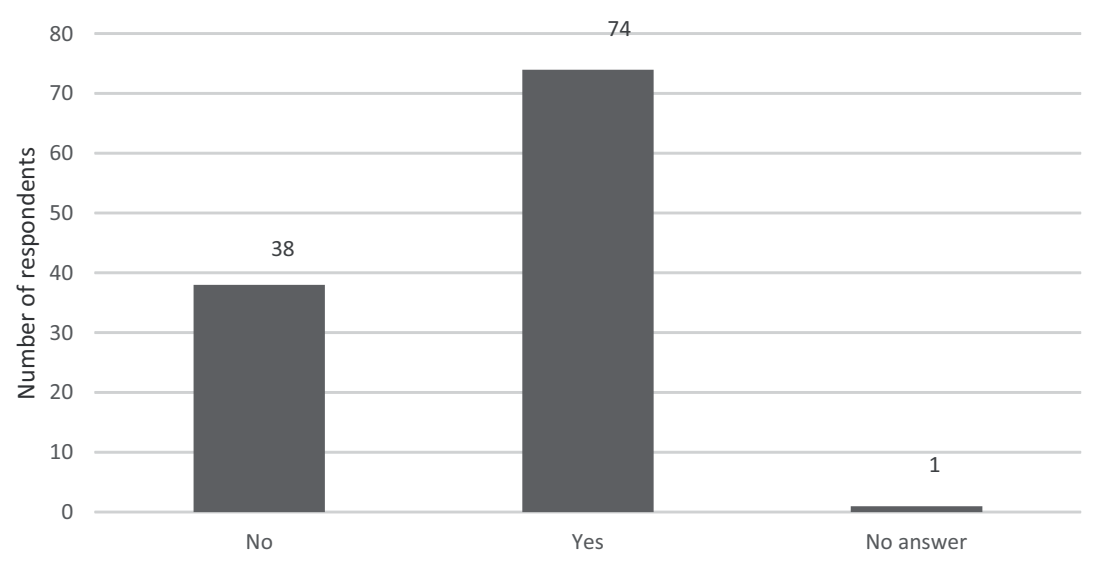

FIG. 2: Distribution of medical personnel answers to question no. 2

Source: author's own study on the basis of gathered study material.

education attended courses in a proper and effective communication with a patient, answers to two another questions show that education within the scope of effective communication with patients in Poland is insufficient (49\%), and medical personnel rather do not attend trainings, conferences, or read literature concerning communication with patients $(49 \%)$.

Another presented hypothesis assumed that medical personnel is satisfied with communication with patients. In regard to that assumption five questions were asked. Firstly, 
3. Do you attend trainings, conferences or read literature concerning a proper communication with a patient?

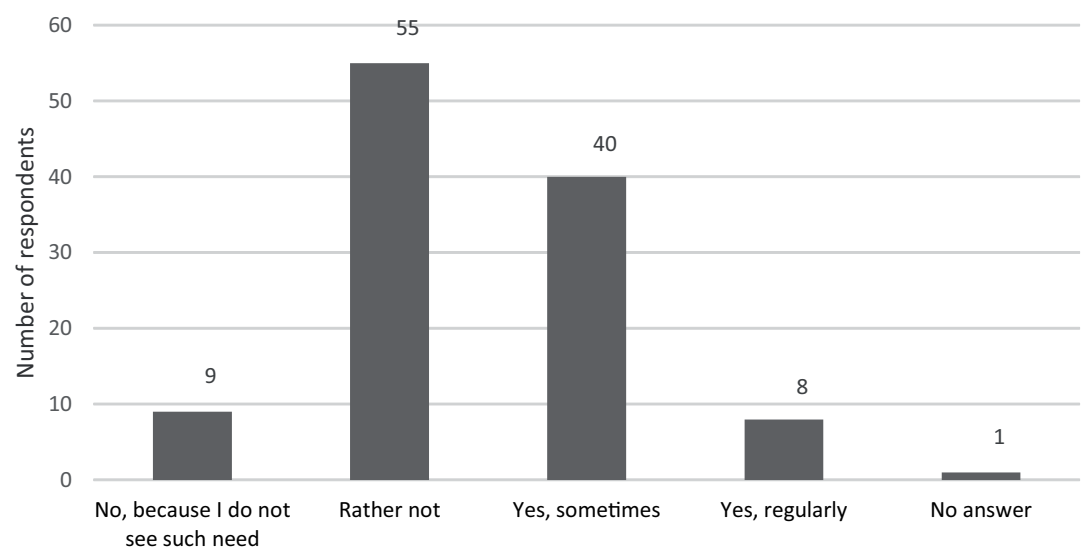

FIG. 3. Distribution of medical personnel answers to question no. 3

Source: author's own study on the basis of gathered study material.

4. During appointment in your office, in spite of stress connected to a specialist visit and discomfort, patients generally are:

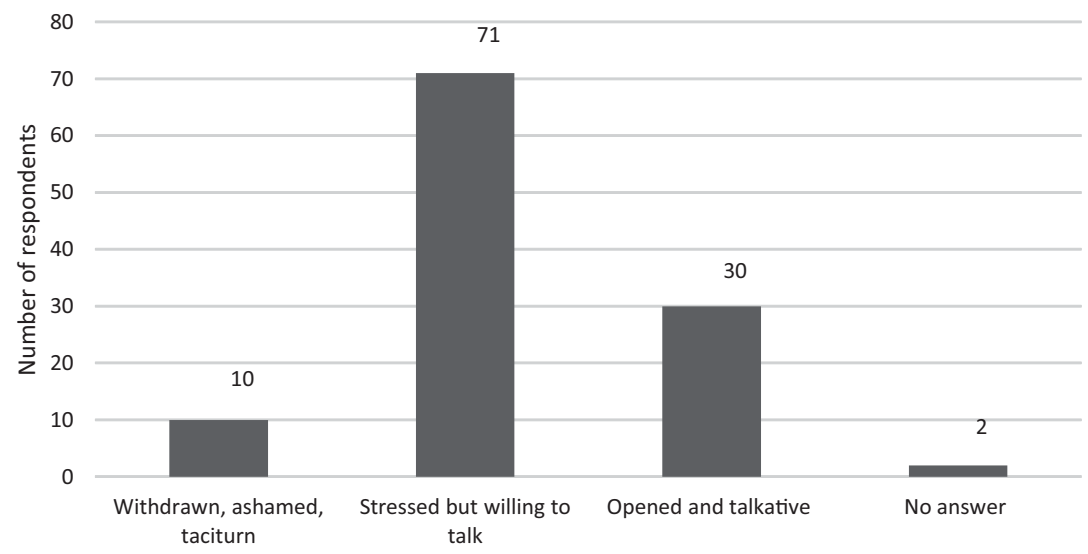

FIG. 4. Distribution of medical personnel's answers to question no. 4

Source: author's own study on the basis of gathered study material.

medical staff were asked about patients' openness in communication with them. $63 \%$ of the staff answered that patients are stressed, but willing to talk to them. A detailed distribution of answers to the question is presented in Figure 4.

In another question respondents were more specifically asked whether patients passively hear recommendations or ask about certain issues. Medical personnel jointly stated $(52 \%)$ that it is difficult to say, as it depends on a patient. A detailed distribution of answers to that question is presented in Figure 5. 
8. Most of your patients generally:

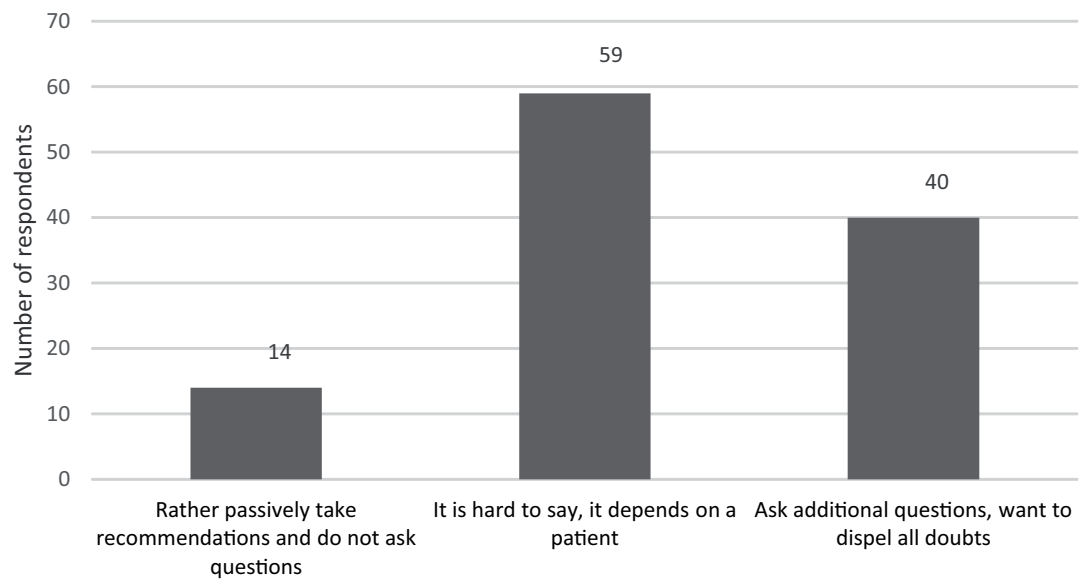

FIG. 5. Distribution of medical personnel's answers to question no. 8

Source: author's own study on the basis of gathered study material.

In the next issue medical staff were asked about patients' attitude towards their recommendations. Most of the respondents (36\%) answered that patients try to observe medical recommendations, however they are not perfect in it. A detailed distribution of answers to this question is presented in Figure 6.

Answers to further questions show that more than a half of respondents (56\%) believe that communication with patients is well. A detailed distribution of answers to that question is presented in Figure 7.

10. Your professional experience sais that patients generally

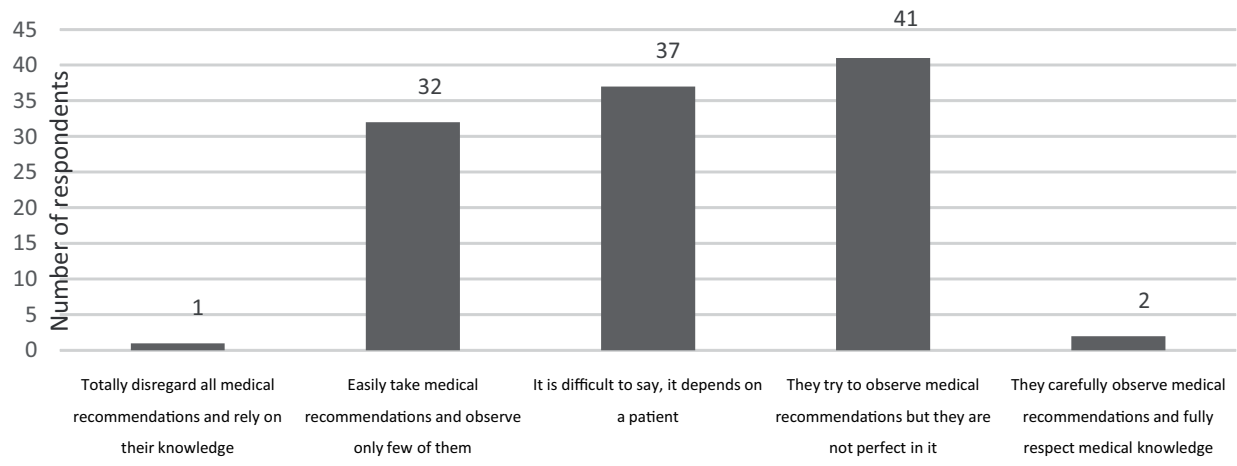

FIG. 6. Distribution of medical personnel's answers to question no. 10

Source: author's own study on the basis of gathered study material. 
11. Communication with patients generally is:

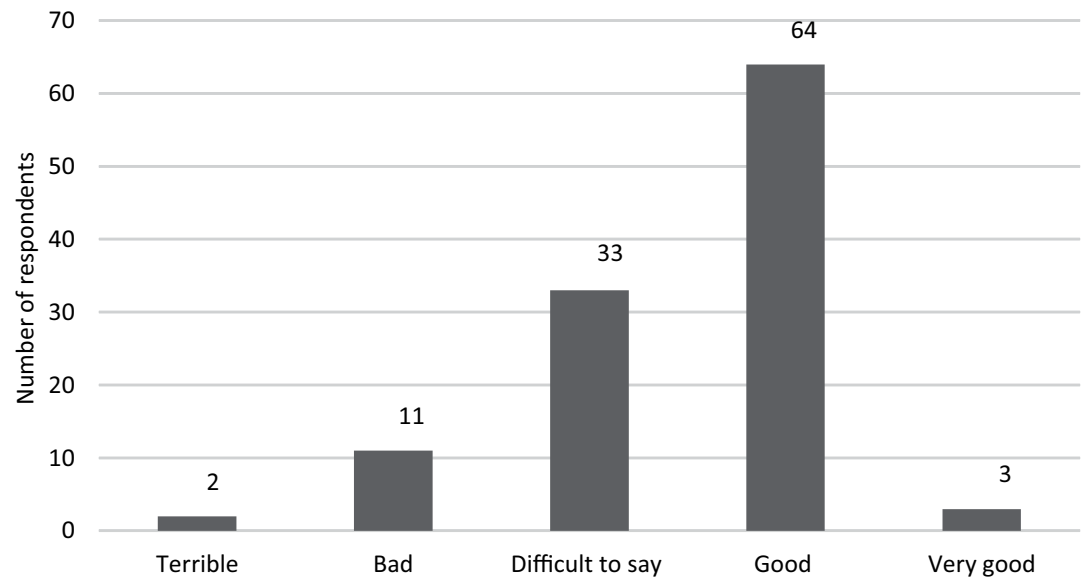

FIG. 7. Distribution of medical personnel's answers to question no. 11

Source: author's own study on the basis of gathered study material.

At the end medical personnel were asked directly to which extent they are satisfied with communication with patients. $69 \%$ of respondents answered that they are quite satisfied. A detailed distribution of answers to this question is presented in Figure 8.

When summing up the second hypothesis, that medical personnel are satisfied with communication with patients, the study results confirm that assumption. Respondent's answers show that it depends on an individual case (52\%) whether a patient passively

12. To which extent are you satisfied with communication with patients?

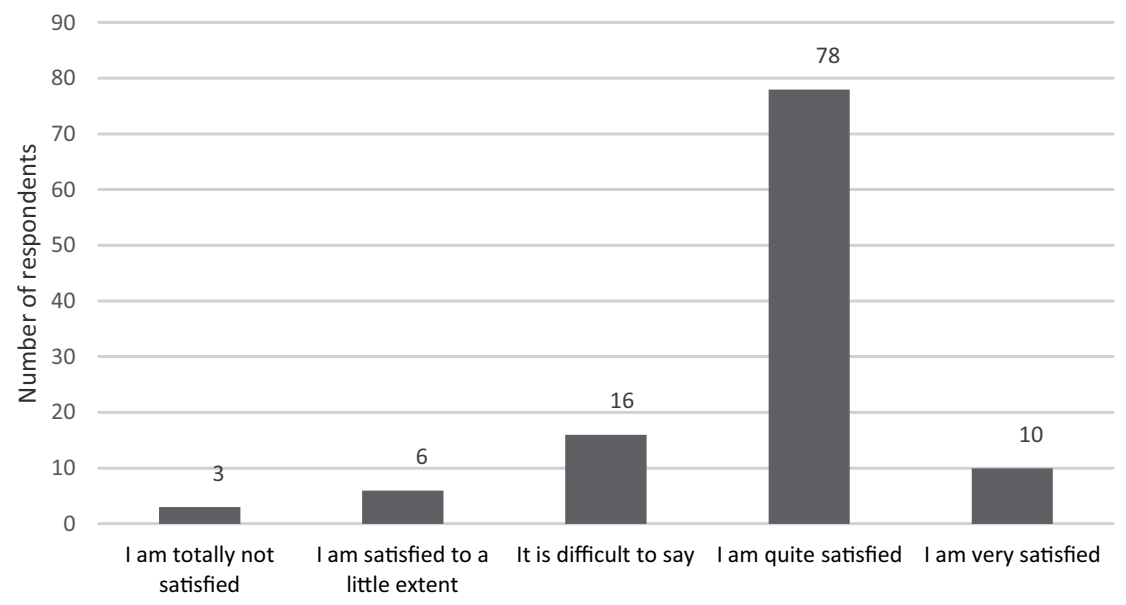

FIG. 8. Distribution of medical personnel's answers to question no. 12

Source: author's own study on the basis of gathered study material. 
accepts medical recommendations or asks additional questions but generally, in spite of little irritation, patients are willing to enter into a conversation $(63 \%)$, try to observe medical recommendations though they are no always perfect in it $(36 \%)$. Medical staff believe as well that communication with patients is good (56\%), and they themselves are quite satisfied with the communication (69\%).

Apart from questions which refer directly to hypotheses, there were few additional issues which may be found helpful in developing conclusions and preparing recommendations. It was found that medical staff largely try to $(46 \%)$, to the extent where it is possible, reduce patient's nervousness and fears. A detailed distribution of answers is presented in Figure 9.

The vast majority of inquired medical personnel claim (80\%) that they try to communicate with patients in a simple, concise way, using words which are commonly understood. A detailed answers distribution is presented in Figure 10.

Respondents also claim that they try to ask patients about physical disorders as well as mental condition (47\%). A detailed answers distribution is presented in Figure 11.

What's more, medical staff declare (46\%) that in the case if a patient has any doubts and the time of an appointment comes to an end, respondents would answer all questions

5. To which extent do you try to reduce patient's tension, nervousness, fears?

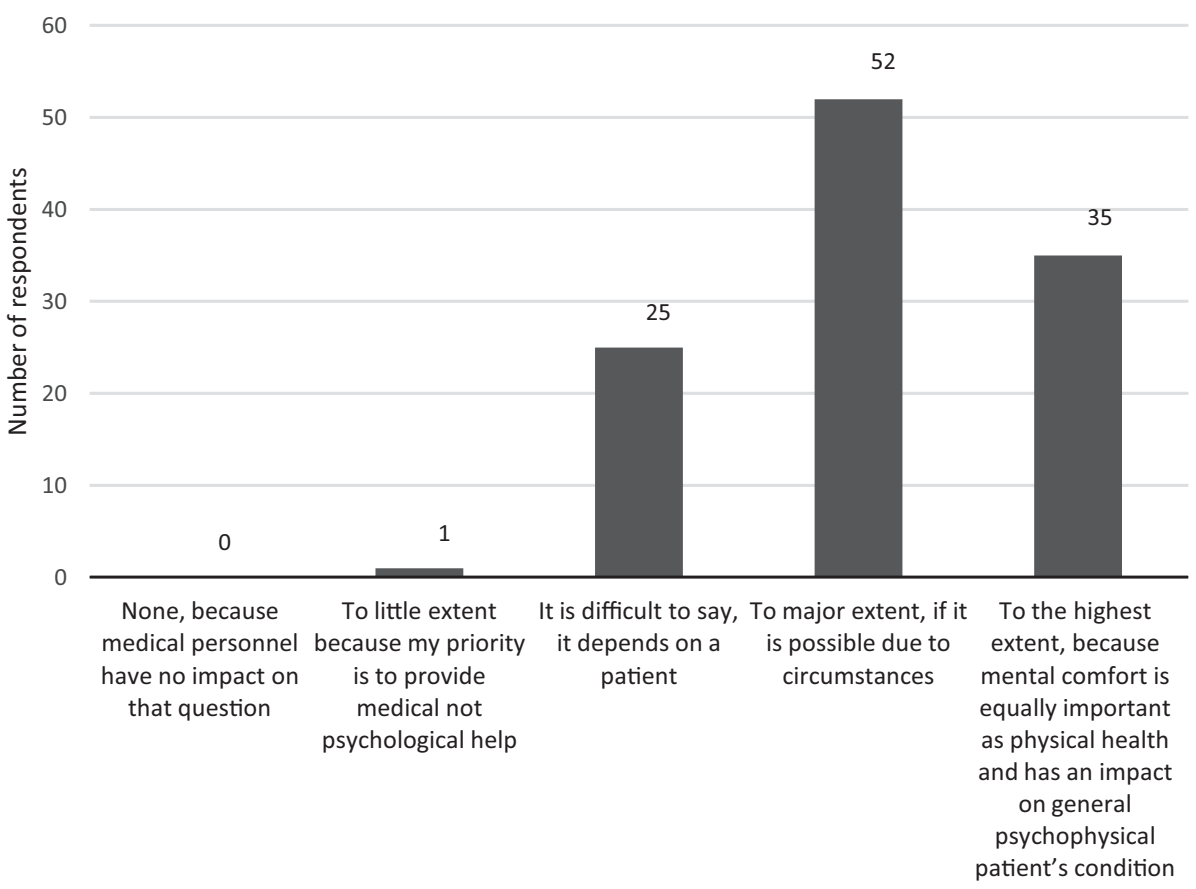

FIG. 9. Distribution of medical personnel's answers to question no. 5

Source: author's own study on the basis of gathered study material. 
6. How do you try to talk to patients?

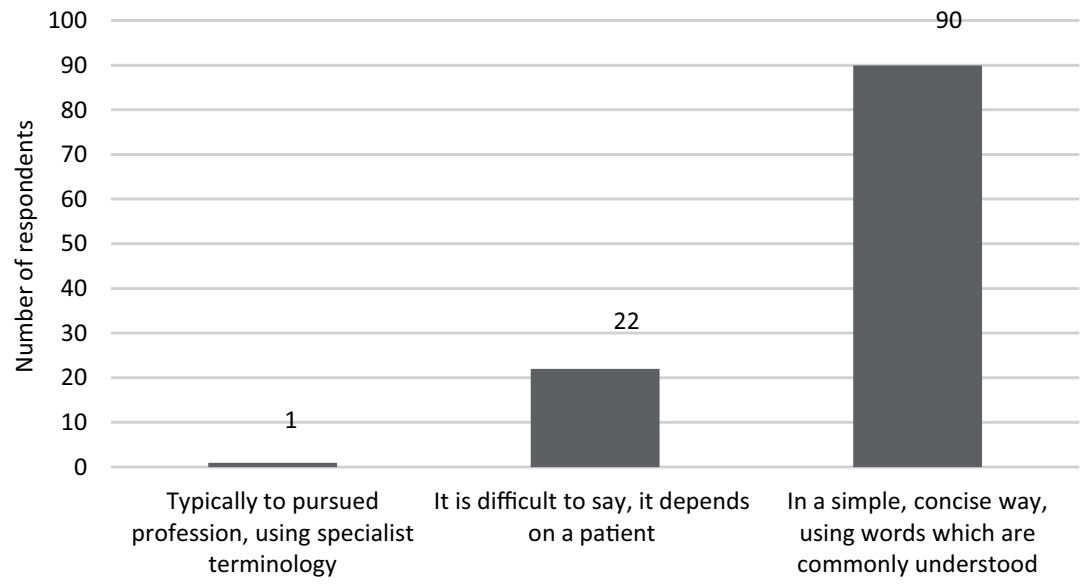

FIG. 10. Distribution of medical personnel's answers to question no. 6

Source: author's own study on the basis of gathered study material.

7. During an appointment you ask about:

60

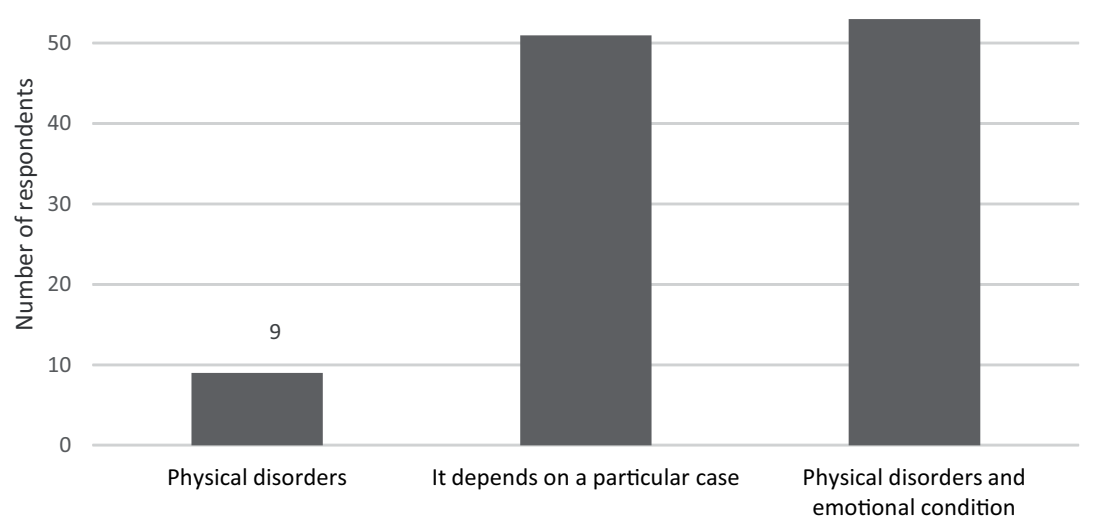

FIG. 11. Distribution of medical personnel's answers to question no. 7

Source: author's own study on the basis of gathered study material.

even if a medical consultation would last longer. A detailed answers distribution is presented in Figure 12.

To sum up, answers to the above questions show that medical personnel have good intentions towards patients. Medical staff seriously try to reduce tension which is related to a specialist appointment (46\%), use a simple and understandable language (80\%), ask 
9. Time of an appointment comes to an end however a patient has few more questions and doubts. What do you do?

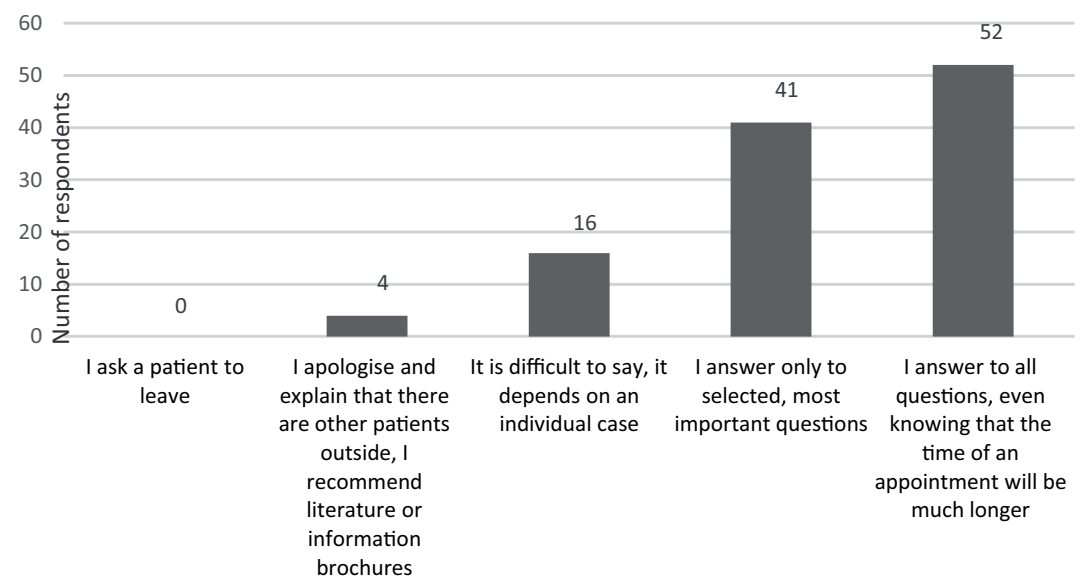

FIG. 12. Distribution of medical personnel's answers to question no. 9

Source: author's own study on the basis of gathered study material.

their patients about physical disorders as well as emotional condition (47\%), answer all their questions even when the time of an appointment will be longer than it was planned $(46 \%)$. This consists an enormous health care organisation developmental potential which ought to be used by a manager in order to make a facility operation more effective.

\section{CONCLUSIONS AND SUMMARY}

Presented results support the keynote of the present article, that communication between a patient and medical personnel is important from medical staff's point of view, and may also influence the management processes in health care organisations.

Research results confirm, that during the educational process only a little of time is dedicated to acquiring communication skills regarding communication between a patient and medical personnel. It also appeared that the medical staff do not attend training courses, conferences or read literature within the scope of proper communication, while highly rating their actions towards patient, trying to answer any patients questions or doubts, and also to reduce stress related to specialist appointment. Still, some kind of paradox may be seen in this situation, as medical personnel notice the need of education in this field, however they do little in this matter, despite sincere intentions regarding contact with patients. Particular need emerges to introduce some institutional arrangements in respect of effective and empathic communication, aimed to medical personnel at the stage of degree programmes education. It should be further continued in lifelong learning, and also should be supported by managers and principals of health care facilities, as it is clearly seen that "medical personnel have substantive competences, acquiring of which in education system, trainings and practical placements is outlined in details (...) Interpersonal skills 
development is poor however, and there is certain lack of systematic solutions regarding their management" [Necki and Kęsy 2013]. It appears, that "both, medical doctors and nurses, claim educational needs in three branches, i.e. knowledge and skills regarding interpersonal communication, skills and knowledge concerning economics and management and actualisation of knowledge and professional medical skills" [Nęcki and Kęsy 2013]. Recent studies revealed, that medical personnel do not read literature, participate in seminars or conferences on communication by themselves. Perhaps, the reason of all of this might be lack of time, which is usually allocated to diverse and numerous duties. However, to assure that those responsible tasks will be properly and efficiently completed, organised form of education in effective communication with a patient should be ensured. Thus, it would be good to utilise positive intensions of medical personnel, starting with organising by a unit manager proper trainings regarding communication with patients. Obviously that education in terms of interpersonal skills can take many forms. Starting with providing medical staff with proper literature concerning communication with a patient, through regular specialists meetings in order to share their remarks and experiences, up to organising seminars, exercises and conferences. A manager should as well continuously motivate medical teams, reminding them how important their work is, and that communication is an inherent element of treatment process and might give many benefits. A director ought to articulate the significance of empathy and an individual way of patients' treatment. It is even more important, as introducing mandatory education within the scope of communication would bring desired effect only when medical personnel's way of thinking about communication will change. It is necessary to begin with values, through attitudes, to actions. A manager should take continuous effort to motivate medical staff to more frequent use of materials concerning proper communication with patients. In turn, classes in communication cannot be perceived as an annoying duty, but as a privilege which will enable medical staff better cooperate with a patient for his/her own benefit, but also for the benefit of whole health care unit.

It must not be forgotten, that contemporary, fast developing society struggles with numerous, progressing diseases of affluence. It is indisputable, that need for health care together with population ageing might get higher and more specialist. This means as well increasing social expectations towards health care facilities and medical staff itself. Relation between medical personnel and patients as well slowly changes. "In the traditional model relation between a doctor and a patient was asymmetric, the first influenced the other, gave advises, treated, prevented his/her diseases and ailments. Current conceptions emphasise a different nature of doctor-patient relation, considering it as mutual, reciprocal influence, and the result of this interaction may contribute to therapeutic success" [Nęcki and Kęsy 2013]. It is even more important, as the communication between medical staff and patients may influence the way health care organisations are managed. Having true, mutual dialogue with a patient, medical staff easier and faster will give a correct diagnosis, what can directly impact patients' satisfaction from provided medical services, and this in turn can cause higher effectiveness of a given health care facility. A patient, to whom sufficient time would be devoted, who will be treated individually, probably will feel respected, heard and understood. Furthermore, when it would be necessary, he/she will return to this health care facility, and maybe will recommend a given institution to his/her own family, friends and acquaintances. He/she will do it, because, as Nęcki and 
Kęsy noticed, current positive image of a health care facility will be mainly based on quality of relations and communication perceived from patients point of view [Nęcki and Kęsy 2013]. Apart from continuous extending of knowledge and improving medical staff qualifications, interpersonal skills will result in successful treatment, therefore in the success of a given facility. With highly qualified medical staff, interpersonal abilities of medical personnel might be a significant factor for competitive advantage. It appears that 'interpersonal abilities, alongside with medical staff professional competences, are currently the factor that might significantly influence the success of whole organisation. These competences, understood as ability to social interaction, play a significant role for medical personnel, revealing themselves in relations with patients' [Nęcki and Kęsy 2013]. Therefore, the role of a manager should be broadly defined assistance to medical services staff education within this scope. Those types of activity are in the interest of whole organisation, because they might significantly increase effectiveness and improve the quality of provided services, and as a result - they might influence the management of health care facility.

Summarising, communication skills are fundamental for functioning in a society, but they appear similarly important in matters of health care and its improvement. They give us ability to give a fast diagnosis and an effective action. However, the communication process between medical personnel and patients is more important as it might appear. Communication skills might also significantly influence on the way health care units are managed. The study showed, that in the course of medical staff education small attention is paid to learn communication with patients, even though medical personnel are satisfied with their relation with patients, and also present a will to support patients in healing process. Analysis of available studies enables to state, that answers to some important issues can be given. However, those issues open wide field for further research. In the future specific aspects of communication should be studied. It is all important not only because of the need for improving the level of soft skills in medical staff, what can significantly influence the level of patients' satisfaction from provided services, but also might influence the way health care facilities are managed.

Last but not least, it should be emphasised, that communication in health care is a very interesting, nevertheless complex issue, to which more interest and attention should be paid in order to improve operation of health care facilities and concerning social health. Medical facilities managers should be obliged not only to maximise the utilisation of staff capabilities, but also to effective management of health care units. They should particularly emphasise comprehensive development of medical staff, as systematic and consequent improvement in medical personnel skills (including i.a. interpersonal abilities), might be a key to successful management of health care units.

\section{REFERENCES}

BARTKOWIAK G., 2010. Psychologiczne aspekty zarządzania zasobami ludzkimi w zakładach opieki zdrowotnej (Psychological aspects of human resources management in healthcare institutions) [in Polish], Wydawnictwo Wolters Kluwer, Warszawa. 
BAUM E., STASZEWSKI R. (eds.), 2008. Profesjonalizm w instytucjach opieki zdrowotnej (Professionalism in healthcare institutions) [in Polish], Wydawnictwo Agrainvest, Wrocław.

DURLIK M., 2008. Zarządzanie w służbie zdrowia. Organizacja procesowa i zarządzanie wiedzą (Healthcare management. Process organization and knowledge management) [in Polish], Wydawnictwo Placet, Warszawa.

FREUND B., DORCZAK R., 2016. Development of soft competencies of students of medicine and nursing - analysis of curricula, INTED2016 Proceedings, 1196-1203.

KĘSY M., 2013. Kształtowanie kompetencji menedżerskich personelu medycznego w szpitalach (Shaping management competences of medical personnel in hospitals) [in Polish], Wydawnictwo Uniwersytetu Jagiellońskiego, Kraków.

Kodeks Etyki Lekarskiej (Code of Medical Ethics) [in Polish], Naczelna Izba Lekarska, consolidated text of 02.01.2004.

Kodeks Etyki Zawodowej Pielęgniarki i Położnej Rzeczypospolitej Polskiej (Code of Professional Ethics of a Nurse and a Midwife of the Republic of Poland) [in Polish], Naczelna Izba Pielęgniarek i Położnych z dnia 9 grudnia 2003.

KRZYŻANOWSKA-ŁAGOWSKA U., 2005. Wartości duchowe w etosie pielęgniarskim. Duchowość, humanizm, profesjonalizm, holizm (Spiritual values in the nursing ethos. Spirituality, humanism, professionalism, holism.) [in Polish], Wydawnictwo Ad Vocem, Kraków.

MOTYKA M., 2012. Komunikacja terapeutyczna a pielęgnowanie chorego (Therapeutic communication and nursing the patient) [in Polish] (In:) B. Ogórek-Tęcza, Z. Pucko (eds.), Międzykulturowe i terapeutyczne uwarunkowania współczesnego pielęgniarstwa. Wydawnictwo Państwowej Wyższej Szkoły Zawodowej im. Rotmistrza Witolda Pileckiego w Oświęcimiu, Oświęcim.

NĘCKI Z., KĘSY M. (eds.) 2013. Postawy personelu medycznego wobec zarządzania szpitalem (Attitudes of medical personnel towards hospital management) [in Polish]. Wydawnictwo Uniwersytetu Jagiellońskiego, Kraków.

Rozporządzenie Ministra Nauk i Szkolnictwa Wyższego w sprawie standardów kształcenia dla kierunków studiów: lekarskiego, lekarsko-dentystycznego, farmacji, pielęgniarstwa i położnictwa z dnia 9 maja 2012 r. (Minister of Science and Higher Education regulation of 9 May 2012 concerning education standards for the faculties of: medicine, dentistry, pharmacy, nursing and midwives (Dz.U. of 2012 poz. 631) [in Polish].

RUDAWSKA I., 2006. Ekonomizacja relacji pacjent-usługodawca w opiece zdrowotnej (The economization of the patient-service provider's relationship in health care) [in Polish], Wydawnictwo Naukowe Uniwersytetu Szczecińskiego, Szczecin.

SZULC R.W., 2011. O etyczny wymiar relacji lekarz-pacjent (For the ethical dimension of the doctor-patient relationship) [in Polish], Poznańskie Towarzystwo Przyjaciół Nauk, Poznań.

WALSHE K., SMITH J. (eds.), 2011. Zarządzanie w opiece zdrowotnej (Management in healthcare) [in Polish], Wydawnictwo Wolters Kluwer Business, Warszawa.

WOJTCZAK A. (ed.) 1994. Poradnik komunikowania się lekarza z pacjentem (A guide for communicating the doctor with the patient) [in Polish], Wydawnictwo Lekarskie PZWL, Warszawa. 
Summary. A health care is characterised of creating an individual, specific relation between representatives of health care units and patients, which means that not only medical staff professionalism but also an empathetic attitude towards patients are important questions. Literature regarding the issue of communication with patients is growing, there are as well workshops in an effective communication, nevertheless the topic is still of minor importance. Meanwhile, relations between medical personnel and patients may put a major impact on the quality of health care as well as patients satisfaction with medical services, what is important from a management point of view. A proper way of patients' treatment by medical personnel may result not only in better attitude towards therapy, but also it may influence a more efficient management of health care facilities, as patient satisfied with medical services may recommend an organisation, which may have a positive impact on an institution's image, allowing a manager to focus on more important aspects of an institution management. For the above reasons it is important to get to know medical personnel's attitude to developing as well as improving communication skills in order to provide a holistic patients care, what can significantly influence a health care units management. Medical staff communication skills are important not only from a treatment perspective, but they can also be significant from the perspective of health care organisations management. The study material was gathered in the first quarter of 2014. In the final analysis questionnaires from 113 representatives of various medical professions were taken into consideration. The study results show that in the process of medical professionals education there is only a little attention paid to acquiring communication skills regarding communication between a patient and medical personnel. Also, the hypothesis according to which medical personnel is satisfied with communication with patients was confirmed. Furthermore, medical staff agree in stating that they care for a proper communication with patients. Conclusions coming from the study results may define a specific way of health care units management, which should comprise, among others, financial resources for trainings in medical personnel soft skills improvement.

Key words: communication, health care, patients, medical personnel, management

JEL: I1, I19, M1, M12

Corresponding author: Bożena Freund, Jagiellonian University, Faculty of Management and Social Communication, Institute of Public Affairs, prof. St. Łojasiewicza 4, 30-348 Kraków, Poland, e-mail: bozena.freund@uj.edu.pl

Received: 29.06 .2017

Accepted: 15.04 .2018 